\title{
TAHAPAN BAGI PERAWAT DALAM PENGAMBILAN KEPUTUSAN KLINIS DI RUMAH SAKIT
}

\author{
Fanisa Nur siregar
}

\author{
fanisanursiregar09@gmail.com
}

\section{Latar Belakang}

Pengambilan keputusan merupakan sebuah proses yang mencakup semua penilaian tindakan yang diperlukan untuk membuktikan dan memperlihatkan mana pilihan terbaik dalam menyelesaiakan suatu masalah tertentu. Keputusan secara harfiah berarti pilihan. Pilihan yang dimaksud di sini adalah sebuah pilihan dari dua atau lebih kemungkinan yang ada, atau dapat dikatakan pula sebagai keputusan dicapai setelah dilakukannya pertimbangan dengan memilih satu kemungkinan pilihan yang ada.

Keputusan dibuat untuk mencapai tujuan melalui pelaksanaan atau tindakan. Setiap keputusan adalah akibat dari sebuah proses dinamis yang dipengaruhi oleh banyak kekuatan, pengambilan keputusana bukan merupakan prosedur yang tetap akan tetapi sebuah proses yang terstruktur. Dalam mengambil keputusan tentu di perlukannya proses ataupun tahapan-tahapan. Proses pengambilan keputusan adalah suatu usaha yang rasional untuk mencapai tujuan-tujuan yang telah ditetapkan pada awal dari tahap perencanaan. Prosesnya mulai dan berakhir dengan pertimbangan yang logis.

Dalam pengambilan keputusan tentu akan dihadapkan dengan suatu masalah. Pemecahan masalah termasuk dalam langkah proses pengambilan keputusan. Tetapi, tidak semua pengambilan keputusan dimulai dengan masalah. Pemecahan masalah dan pengambilan keputusan saling berkaitan dan efektif diprediksi bahwa individu harus memiliki kemampuan untuk berfikir kritis dan mengembangkan dirinya dengan adanya bimbingan di lingkungan kerjanya. Pengambilan keputusan dalam penyelesaian masalah adalah sebuah kemampuan mendasar bagi praktisi kesehatan, khususnya dalam asuhan keperawatan. 
Tenaga kesehatan perlu memiliki kemampuan dalam pengambilan keputusan yang tepat dan akurat terkhusus untuk perawat dalam memberikan asuhan keperawatan untuk dapat menyelamatkan pasien yang dihadapi. Ketika menjalankan tugasnya, seorang perawat pasti akan dihadapkan dengan suatu keadaan dimana perawat tersebut akan memutuskan tentang kondisi kesehatan klien atau pasien yang sedang ia tangani. Kondisi kesehatan pasien yaitu terdiri dari pasien yang sehat dengan pasien yang sakit. Dalam memberikan asuhan keperawatan perawat sebagai tenaga kesehatan tentu perlu mengambil keputusan apa yang akan di berikan kepada klien. Perawat melakukan pengambilan keputusan sebelum melakukan tindakannya. Pengambilan keputusan juga sangat penting keberadaannya dalam asuhan ataupun manajemen keperawatan. Seorang perawat harus mampu mengambil keputusan klinis dengan melibatkan pasien dan keluarga dalam asuhan keperawatannya.

\section{Metode}

Metode dalam pembuatan jurnal ini dilakukan dengan cara mengumpulkan data dari buku, jurnal, dan thesis dan e-book, kemudian melakukan analisis secara mendalam terkait topik yang dibahas, serta bersifat subjektif yaitu proses penulisan yang lebih fokus pada landasan teori. Dan melakukan analisis buku dan e-jurnal yang relevan dan berfokus pada Tahapan Bagi Perawat Dalam Pengambilan Keputusan Klinis Di Rumah Sakit. Dengan menggunakan sumber dengan terbitan paling tua tahun 2012. Adapun referensi akan dicantumkan dalam penulisan ini dengan jelas terdapat pada daftar pustaka pada bagian akhir penulisan.

\section{Hasil}

Pengambilan keputusan yang tepat akan menghasilkan suatu perubahan terhadap individu, kelompok maupun masyarakat ke arah yang lebih baik, namun sebaliknya pengambilan keputusan yang salah akan berdampak buruk pada keadaan seseorang. Keputusan yang baik terjadi jika pengambil keputusan sepenuhnya mengerti latar belakang, tujuan dan sasaran, alternatif penyebab tindakan, serta konsekuensikonsekuensi yang mungkin timbul dari keputusan.

Berpikir kritis penting dilakukan oleh perawat sebelum mengambil keputusan dalam asuhan keperawatan.Asuhan keperawatan merupakan satu metode ilmiah dalam penyelesaian masalah klien. Kemampuan perawat mengidentifikasi masalah klien dan memilih solusi 
intervensi yang tepat tidak lepas dari kemampuan perawat berpikir kritis, yaitu kemampuan perawat menggali alas an dari setiap masalah dan solusi yang teridentifikasi. Menurut Manulang (1994) ada lima tahap dalam mengambil keputusan yaitu :

- Tahap 1 menerima tantangan.

- Tahap 2 mencari alternatif.

- Tahap 3 penilaian alternatif.

- Tahap 4 menjadi terikat.

- Tahap 5 berpegang pada keputusan.

Pengambilan keputusan merupakan proses pemecahan masalah yang berfokus pada analisa situasi yang sulit untuk mengambil solusi yang memutuskan permasalah tersebut. Oleh karena itu seorang perawat dituntut untuk dapat memutuskan sesuatu dengan baik dan tidak merugikan orang lain yang berlandaskan etika profesi keperawatan. Dalam pengambilan keputusan perawat harus mempertimbangkan segala aspek, baik dari pasien itu sendiri, keluarga pasien, tenaga kesehatan lain, dan psiko, sosial, dan cultural yang diterapkan.

\section{Pembahasan}

Keputusan secara harfiah berarti pilihan. Pilihan yang dimaksud di sini adalah pilihan dari dua atau lebih kemungkinan, atau dapat dikatakan pula sebagai keputusan dicapai setelah dilakukan pertimbangan dengan memilih satu kemungkinan pilihan yang ada. Seperti yang diungkapkan oleh Gito Sudarmo, bahwa keputusan terkait dengan ketetapan atau penentuan suatu pilihan yang diinginkan.

Keputusan klinis adalah suatu proses yang meliputi diagnosis klinis, penilaian dan keputusan tentang apa yang harus dilakukan (Ennis 1996). Urutan langkah-langkahnya yaitu sebagai berikut:

1) Penentuan masalah,

2) Analisa situasi yang ada,

3) Pengembangan alternatif-alternatif,

4) Analisa alternatif-alternatif,

5) Pilihan alternatif yang paling baik 
Tujuan pengambilan keputusan dapat dibedakan menjadi :

1) Tujuan yang bersifat tunggal. Tujuan pengambilan keputusan yang bersifat tunggal terjadi apabila keputusan yang dihasilkan hanya menyangkut satu masalah, artinya bahwa sekali diputuskan, tidak ada kaitannya dengan masalah lain

2) Tujuan yang bersifat ganda. Tujuan pengambilan keputusan yang bersifat ganda terjadi apabila keputusan yang dihasilkan menyangkut lebih dari satu masalah, artinya keputusan yang diambil itu sekaligus memecahkan dua (atau lebih) masalah yang bersifat kontradiktif atau yang bersifat tidak kontradiktif.

Cooke \& Slack (1991) menjelaskan 9 tahap yang dilalui individu dalam mengambil keputusan yaitu:

$>$ Observasi.

Disini individu perlu memperhatikan bahwa ada sesuatu yang keliru atau tidak sesuai, sesuatu yang merupakan sebuah kesempatan untuk memutuskan apa yang sedang terjadi pada lingkungannya. Suatu kesadaran bahwa keputusan sedang diperlukan. Kesadaran ini diikuti oleh satu periode perenungan seperti proses inkubasi.

Mengenali masalah.

Sesudah melewati masa perenungan, atau karena akumulasi dari banyaknya bukti bukti atau tanda-tanda yang tertangkap, maka individu akan menyadari bahwa kebutuhan untuk memutuskan sesuatu menjadi nyata.

Menetapkan tujuan.

Fase ini adalah masa individu untuk mempertimbangkan harapan yang akan dicapai dalam mengambil sebuah keputusan. Tujuan ini umumnya berkaitan dengan kesenjangan antara sesuatu yang telah diobservasi dengan sesuatu yang diharapkan, berkaitan dengan permasalahan yang dihadapi.

> Memahami masalah. 
Merupakan suatu kebutuhan bagi individu untuk memahami secara benar permasalahan yang terjadi, yaitu mendiagnosa akar permasalahan yang terjadi. Kesalahan dalam mendiagnosa dapat terjadi karena mendefenisikan masalah secara salah, karena hal ini akan mempengaruhi proses selanjutnya.

Menentukan Pilihan pilihan.

Jika batas batas keputusan telah didefinisikan dengan lebih sempit maka pilihan-pilihan dengan sendirinya lebih mudah Namun, jika keputusan yang diambil masih didefinisikan secara luas maka proses menetapkan pilihan merupakan proses kreatif.

$>$ Mengevaluasi Pilihan pilihan.

Fase ini melibatkan penentuan yang lebih luas mengenai ketepatan masing- masing pilihan terhadap tujuan pengambilan keputusan.

$>$ Memilih.

Pada fase ini salah satu dari beberapa pilihan keputusan yang tersedia telah dipilih, dengan pertimbangan apabila diterapkan akan menjanjikan suatu kepuasan diri.

$>$ Menerapkan.

Fase ini melibatkan perubahan- perubahan yang terjadi karena pilihan yang telah dipilih. Efektivitas penerapan ini bergantung pada ketrampilan dan kemampuan individu dalam menjalankan tugas serta sejauh mana kesesuaian pilihan tersebut dalam penerapan.

\section{Memonitor.}

Setelah diterapkan, maka keputusan tersebut sebaiknya dimonitor atautpun diawasi untuk melihat keefektivitasan dalam memecahkan masalah atau mengurangi permasalahan yang sesungguhnya.

Thohiron menjelaskan proses pengambilan keputusan meliputi sebagai berikut.

1. Perumusan Masalah 
Dalam hal ini perawat diharapkan mampu merumuskan masalah yang ada di dalam memberikan asuhan keperawatan. Suatu masalah hadir karena adanya kesenjangan antara kenyataan dengan tujuan yang ingin diraih atau standar yang ingin dicapai, adanya halangan dan kesulitan untuk menjembatani kesenjangan itu, adanya kemungkinan penyelesaian masalah bila perumusannya benar. Perumusan masalah juga terkait dengan sudut pandang. Sebuah perumusan yang baik mengidentifikasikan semua elemen-elemen yang relevan Perumusan masalah dimulai dengan mengkaji fakta-fakta yang ada.

\section{Pengumpulan dan Penganalisis Data}

perawat diharapkan dapat mengumpulkan dan menganalisis data yang di dapat ketika melakukan pengkajian. Adapun proses pemecahan masalah dalam pengambilan keputusan yaitu:

b. fase pengumpulan fakta;

c. fase penemuan ide;

d. fase penemuan solusi.

3. Pembuatan alternatif-alternatif kebijakan

Setelah masalah dirinci dengan tepat dan tersusun baik, maka perlu dipikirkan cara-cara pemecahannya. Cara pemecahan ini hendaknya selalu diusahakan adanya alternatif-alternatif beserta konsekuensinya, baik positif maupun negatif. Oleh sebab itu, seorang perawat harus dapat mengadakan perkiraan sebaik-baiknya. Untuk mengadakan perkiraan dibutuhkan adanya informasi yang secukupnya dan metode perkiraan yang baik.

4. Pemilihan salah satu alternatif terbaik

Pemilihan satu alternatif yang dianggap paling tepat untuk memecahkan masalah tertentu dilakukan atas dasar pertimbangan yang matang atau rekomendasi. Dalam pemilihan satu alternatif dibutuhkan waktu yang lama karena hal ini menentukan alternatif yang dipakai akan berhasil atau sebaliknya. Pengambilan keputusan oleh pimpinan, kaitannya dengan pemilihan alternatif pemecahan masalah, akan melibatkan semua pihak yang terlibat dalam lembaga pendidikan. Hal ini karena kekuasaan pimpinan tidak dapat dioperasionalkan apabila tidak didukung dan dibantu oleh seluruh personal yang memiliki pengetahuan dan pengalaman yang berbeda-beda. Pimpinan harus mengembangkan konsep kerja sama antar personal agar 
pelaksanaan alternatif pemecahan masalah lebih cepat dan mudah. Kerja sama dapat diciptakan jika pimpinan memiliki keterampilan manusiawi.

5. Pelaksanaan keputusan

Dalam pelaksanaan keputusan berarti seorang perawat harus mampu menerima dampak yang positif atau negatif. Ketika menerima dampak yang negatif, perawat harus juga mempunyai alternatif yang lain.

6. Pemantauan dan Pengevaluasian

Hasil Pelaksanaan Setelah keputusan dijalankan seharusnya perawat dapat mengukur dampak dari keputusan yang sudah dibuatnya. Penilaian ulang perlu diadakan. Faktor-faktor penentu yang akan dinilai harus diputuskan sejak awal dan tidak setelah pelaksanaan berjalan.

Keputusan yang diambil akan dapat diasumsikan baik bila telah memenuhi ketentuanketentuan sebagai berikut:

a. keputusan diambil sebagai pemecahan masalah yang dihadapi;

b. sedapat mungkin cepat dan tepat;

c. bersifat rasional, artinya dapat diterima akal sehat terutama bagi para pelaksana yang nantinya bertanggung jawab atas keputusan tersebut;

d. bersifat praktis dan pragmatis, artinya dapat dilaksanakan dengan kemampuan yang ada;

e. berdampak negatif seminim mungkin;

f. menguntungkan banyak pihak demi kelancaran kerja dan arah tujuan yang hendak dicapai;

g. keputusan yang diambil dapat dievaluasi untuk masa yang akan data

Dengan demikian di dalam mengambil sebuah keputusan, harus memperhatikan hal-hal sebagai berikut:

1) Dalam proses pengambilan keputusan tidak terjadi secara kebetulan; 
2) Pengambilan keputusan dilakukan secara sistematik, yaitu: tersedianya sumber-sumber untuk melaksanakan keputusan yang akan diambil, kualifikasi tenaga kerja yang tersedia, falsafah yang dianut organisasi, situasi lingkungan internal dan eksternal yang akan mempengaruhi administrasi dan manajemen di dalam organisasi;

3) Masalah harus diketahui dengan jelas;

4) Pemecahan masalah harus didasarkan dengan fakta-fakta yang dikumpulkan secara sistematis;

5) Keputusan yang baik adalah keputusan yang telah dipilih dari berbagai alternatif yang telah dianalisa secara matang.

\section{Penutup}

Pengambilan keputusan merupakan unsur yang sangat penting dalam keperawatan. Hal ini karena pengambilan keputusan berkaitan dengan asuhan keperawatan yang akan diberikan perawat kepada pasien. Perawat memiliki tanggung jawab untuk mengambil langkah - langkah keperawatan yang akan dilakukan dengan standar keperawatan dalam pengambilan keputusan. Perawat harus berani dalam mengambil keputusan terkait dengan asuhan keperawatannya kepada klien. Keputusan yang baik terjadi jika pengambil keputusan sepenuhnya mengerti latar belakang, tujuan dan sasaran, alternatif penyebab tindakan, serta konsekuensikonsekuensi yang mungkin timbul dari keputusan.

\section{Daftar Pustaka}

Anwar, H. (2014). Proses Pengambilan Keputusan untuk Mengembangkan Mutu Madrasah. Jurnal Pendidikan Islam Vol 8 No 1, 38-56.

Deniati , K., \& dkk. (2018). PENGARUH BERFIKIR KRITIS TERHADAP KEMAMPUAN PERAWAT PELAKSANA DALAM MELAKUKAN ASUHAN KEPERAWATAN DI RUMAH SAKIT HERMINA BEKASI TAHUN 2016. Jurnal Kesehatan Holistik (The Journal of Holistic Healthcare), Volume 12, No.1, 21-25.

Isnaini, N. M., \& Rofii, M. (2014). Pengalaman Perawat Pelaksana dalam Menerapkan Keselamatan Pasien. Jurnal Manajemen Keperawatan, 2(1), 30-37.

Khairina, I., \& dkk. (2018). FAKTOR-FAKTOR YANG BERHUBUNGAN DENGAN PENGAMBILAN KEPUTUSAN PERAWAT DALAM KETEPATAN TRIASE DI KOTA PADANG. Indonesian Journal for Health Sciences Vol.2, No.1, 1-6. 
Muhdi., \& dkk. 2017. Teknik Pengambilan Keputusan Dalam Menentukan Model Manajemen Pendidikan Menengah. Jurnal Manajemen Pendidikan. 4 (2). hal 134 - 145

Moordiningsih dan Faturochman. 2015. Proses Pengambilan Keputusan Dokter (Physician Decision Making). Jurnal Psikologi. 33 (2). hal $1-15$

Nisa, Ika Filana Saidatun. (2017). Hubungan Tingkat Kepatuhan dan Pengambilan Keputusan Etis dengan Keberhasilan Terapi Pengobatan Pasien Hipertensi Primer di Puskemas Dinaoyo Kota MalangPhD. Thesis. University of Muhammadiyah Malang.

Purwati, E., \& dkk. (2017). Pengambilan Keputusan dalam Pelaksanaan Rujukan Puskesmas sebagai Fasilitas Kesehatan Tingkat Pertama. e-Jurnal Pustaka Kesehatan, Vol. 5, No. 2, 231-238.

Rahayu, C. D., \& Mulyani, S. (2020). PENGAMBILAN KEPUTUSAN KLINIS PERAWAT. Jurnal Ilmiah Kesehatan, 1-11.

Simamora, R. H. (2005). Hubungan Persepsi Perawat Pelaksana Terhadap Penerapan Fungsi Pengorganisasian Yang Dilakukan Oleh Kepala Ruangan Dengan Kinerjanya Diruang Rawat Inap RSUD Koja Jakarta Utara (Doctoral dissertation, Tesis FIK UI, Tidak dipublikasikan).

Simamora, R. H. (2019). Menjadi perawat yang: CIH'HUY. Surakarta: Kekata Publisher. Sumijatun. (2009). Konsep Dasar dan Aplikasi Pengambilan Keputusan Klinis. Jakarta: Trans Info Media Jakarta.

Sudono, B., \& dkk. (2017). GAMBARAN KEMAMPUAN BERPIKIR KRITIS PERAWAT PRIMER DALAM PELAKSANAAN ASUHAN KEPERAWATAN DI RUMAH SAKIT ISLAM SURAKARTA. Jurnal Ilmu Keperawatan Indoensia Vol. 10, No. 1, 79106. 